\title{
İspanya'da Geleneksel Quart Çömlekçiliği ve Siyah Pişirim
}

\author{
Prof. Sibel Sevim \\ Dr. Öğr. Üyesi Cemalettin Sevim \\ Doç. Ezgi Hakan Verdu Martinez
}

\section{Özet}

Bu çalışma İspanya'nın Katalonya Bölgesi Girona şehrine bağlı olan ve siyah renkli karakteristik ürünleri ile tanınan seramik merkezi Quart' In Siyah Çömlekçilik mirasını anlatan bir araştırmadır. 15 gün süren ve 2 katlı özel firınlarda yapılan redüksiyonlu siyah pişirim günümüzde Quart'ta sadece birkaç atölyede sürdürülmekte olup, yaklaşık 300 yıllık siyah pişirim geleneği bu atölyeleri işleten aileler tarafından kuşaktan kuşağa aktarılarak günümüze taşınmıştır. Ayrıca yaklaşık 90 yıllık bir tuğla fabrikasının restore edilmesi ile 2010 yılında açılan La Terissa de Quart Müzesi, siyah pişirim geleneğini canlı tutmayı amaçlarken, çeşitli seramik etkinliklerine ev sahipliği yaparak bu geleneği tanıtmakta ve yeni kuşaklara aktarmaktadır.

Anahtar Sözcükler: Seramik, Çömlekçilik, Siyah Pişirim, Gelenek

\section{TRADITIONAL QUART POTTERY AND BLACK FIRING IN SPAIN}

\begin{abstract}
This research is based on the Black fired pottery heritage of Quart village, in Girona city in Catalonia known with the characteristic black colored products. The reduction firing realized in 2 layered special kilns, during 15 days, is continued in only a couple of studios in Quart today; meanwhile this tradition is conveyed from generation to generation since 300 years being performed in family workshops and manufactories. With the aim to keep this tradition of black pottery alive, La Terissa Quart Museum has been established in 2010, after restoration of a 90 years old brick factory. This institution has been holding the mission of hosting many ceramic organizations transfering the tradition to new generations, by means of introducing black pottery and firing technique.
\end{abstract}

Keywords: Ceramic, Pottery, Black Firing, Tradition

Prof. Sibel Sevim Anadolu Üniversitesi, Güzel Sanatlar Fakültesi, Seramik Bölümü, Eskişehir.

E-posta: sssevim@anadolu.edu.tr

Dr. Öğr. Üyesi Cemalettin Sevim, Anadolu Üniversitesi, Güzel Sanatlar Fakültesi, Seramik Bölümü,

Eskişehir. E-posta: csevim@anadolu.edu.tr

Doç. Ezgi Hakan Verdu Martinez, Anadolu Üniversitesi, Güzel Sanatlar Fakültesi, Seramik Bölümü, 


\section{Giriş}

Toplumlar varlıklarını sürdürebildikleri süreç içinde kendi kültürlerini ve geleneklerini oluştururlar. Gelenekler, geçmiş zamanda edinilmiş ve toplum tarafından benimsenerek kuşaktan kuşağa aktarılmış bilgi, davranış, alışkanlık, töre ve uygulamalardır. Bir başka ifade ile Tatar'ın da belirttiği gibi 'Gelenek, çoğu kere sığ ve genel geçer bir biçimde kavrandığı şekliyle örf ve âdetler değil, örf ve âdetler de içerisinde olmak üzere, bir tarihî-kültürel mirasın total haliyle bizzat kendisidir. Yani milletin hayatındaki ortak inanç ve pratiklerin düzenlenme biçimleridir' (Tatar, 2000, 199). Bu nedenle gelenekler, toplumları birbirinden ayıran ve farklı kılan en önemli özelliklerdendir. Çömlekçilik sanatı da bu geleneklerden bir tanesi olup, içinde bulunduğu kültürün, zamanın ve mekânın, toplumsal yapının özelliklerini en net biçimde ortaya koyan işlevsel sanatlar arasında yer alır. Sanatın işlevselliği kullanılabilir olma özelliğinden kaynaklanmaktadır. Geleneksel sanatlarda bir objenin kullanılabilirliği ve kullanım özellikleri toplumun kültürüne bağlı olarak gelişerek, biçimlenir. Bu bağlamda Quart çömlekçiliği Katalan kültürüne has fonksiyonel siyah renkli formlarıly seramik sanatında ve tarihinde geleneksel bir önem kazanmıştır.

İspanya'nın Katalonya Bölgesi Girona şehrine bağlı Quart köyü siyah renkli karakteristik ürünleri ile tanınan bir seramik merkezidir. İber yarımadasında ilk yerleşim yeri olan La Creueta'da rastlanan çömlek kalıntıları Quart'ta insan yaşamını kanıtlayan ilk izlerdir. Quart'ta neolitik çağa kadar uzanan seramik kültürü orta çağda kurulan üretim merkezlerinde devam etmiştir. Kayıtlara göre, Quart ürünlerinin 1312'de Girona'da vergiye tabi tutularak satıldığı bilinmektedir. Quart, siyah pişirim yapılarak karakteristik hale gelen ürünleri ile tanınan bir seramik merkezi olmuştur. Quart'ta seramikçiler birliği locası 1572 yılında kurulmuş ve 1988 yılında zanaatkârlar birliğine dönüşmüştür. 1484 e ait belgeler Pere ve Bartomeu Tauler'in Quart'ta üretim yaptığını, 1511 de La Bisbal'de, 1583'te ise Breda'da üretimin bulunduğunu kanıtlamaktadır (Quart müze kataloğu, s:3).

\section{Geleneksel Quart Çömlekçiliği}

Quart'ta günümüze kadar uzanan çömlekçilik 18.yy. başında başlamıştır. En haraketli dönemlerinde bölgede atölye sayısı 30'a kadar çıkmıştır. 1960 'lar geleneksel üretimler ve ticaretin endüstri ürünlerinden etkilendiği ve bölgede atölyelerin kapanmaya başladığı yıllar olmuştur. Quart'ın her yerine dağılan yaygın aile işletmelerinden bugün sadece 5 atölye ayakta kalabilmiştir. Bu atölyeler geleneksel üretimlerine devam ederek geçimlerini sağlarken, onlar sayesinde Quart'ta çömlekçilik ruhu da sürdürülmektedir. Günümüzde Quintana, Prats, Marco, Bonadona ve Mestres isimli 5 aile 
atölyesi hala aktif olarak çalışmaktadır.

Gelenek, ihtiyaçları karşılayamaz hale gelince zaman içinde değerini kaybetmeye başlar. Kendi içerisinde sürekliliğine ilave olarak az da olsa bir değişimi taşır; gelecek de aslında ruhunu, bu değişen geleneklerden alır ve kabul görür (Tatar, 2000, 201). Quart'ta da değişen şartlara göre farklı üretimler yapılsa da, bölgede belli başlı geleneksel üretimler hakim olmuştur. Özellikle 19. yy.dan bu yana testi, küp gibi mutfak kapları, tuğla, çatı kaplaması, karo gibi inşaat malzemeleri ve bahçe seramikleri gibi çeşitli üretimler az da olsa değişerek yapılagelmiştir.

Bu üretimlerin yanı sıra yeme içme kültürünün gereksinimlerini karşılayan çömlek formları da üretilmiştir. Bu formlar suyu çıkarmak, taşımak, depolamak, zeytini salamura etmek, yağ ve şarap gibi sıvıları saklamak, yemek pişirmek ve servis etmek gibi ihtiyaçların yanında, çamaşır yıkama, yağ damıtma ve şarap yapımı gibi amaçlar için de kullanılmıştır.

Su taşımak için kullanılan testi formu bölgenin simgesi haline gelmiştir. Katalanca "cantir" i̇spanyolcada "botigo"olarak bilinen testi, ỉber yarımadasında geleneksel bir form olarak bilinmektedir. Formun su doldurulan ve içilen iki ağzı ve bunların ortasında tutmak için bir kulpu bulunur. Bu form Quart'ta da karakteristik bir form olarak günümüze dek üretile gelmiştir. Günümüzde Quart'ta hem siyah pişirim hem de normal pişirimle üretilen örnekleri mevcuttur. İşlevsel olarak kullanımı devam etmediği için, dekoratifve koleksiyon objesi olarakilgi görmektedir. Quart'ın da bulunduğu Katalonya Bölgesinde yer alan Argentona çömlekçi yerleşim yerinde sadece bu testi türünün çeşitleri ve tarihini anlatan 400'den fazla formun yer aldığı zengin koleksiyonuyla Cantir Müzesi bulunmaktadır. Ayrıca La Bisbal'de yer alan seramik müzesinde de siyah pişirimle üretilmiş Cantir kültürünü anlatan bir bölüm bulunmaktadır.

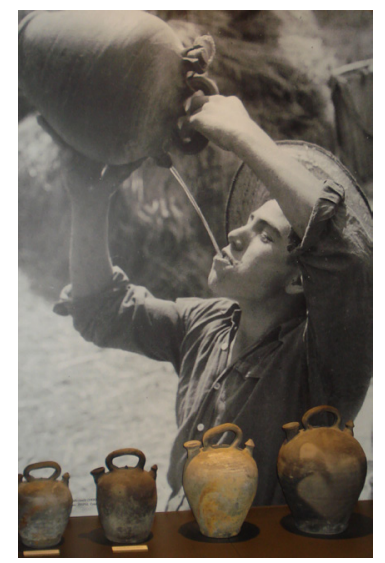




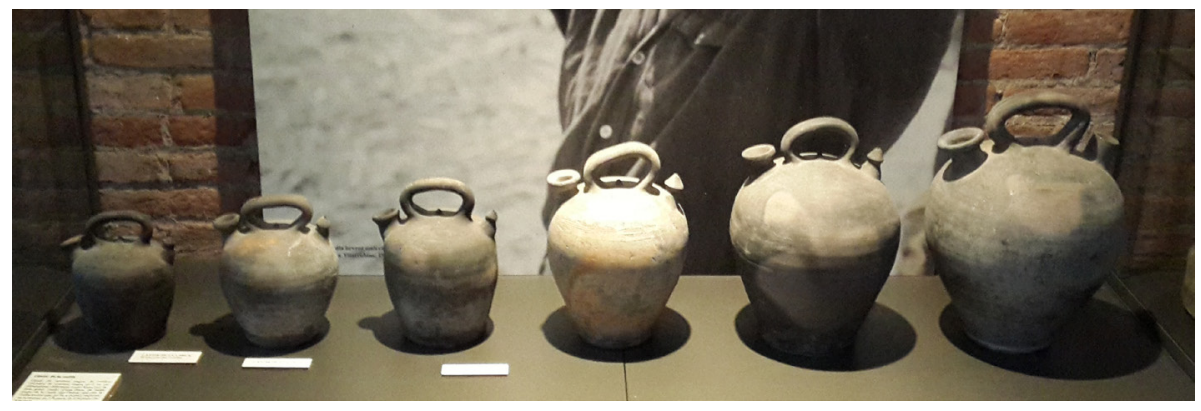

Görsel I-2. İspanya'ya özgü testi formu, botigo, cantir testi

Bu üretimlerin dışında yörede hayvanlara su vermek, yatağı ve ayakları ısıtmak, kestane kavurmak, bal peteğini kovandan ayırmak amacıyla arıları kaçırmak, hayvanları beslemek, kuş ve tavuklara su vermek, ahtapot yakalamak üzere bazı özel amaca yönelik üretilmiş pişmiş toprak formlar da dikkat çekmektedir. Ayrıca mimaride iç ve dış mekânda yer ve duvar kaplamaları, balkon ve merdiven korkulukları ve baca yapımında özel olarak üretilen formlar sıklıkla kullanılmıştır (Celio, 2014: 177).

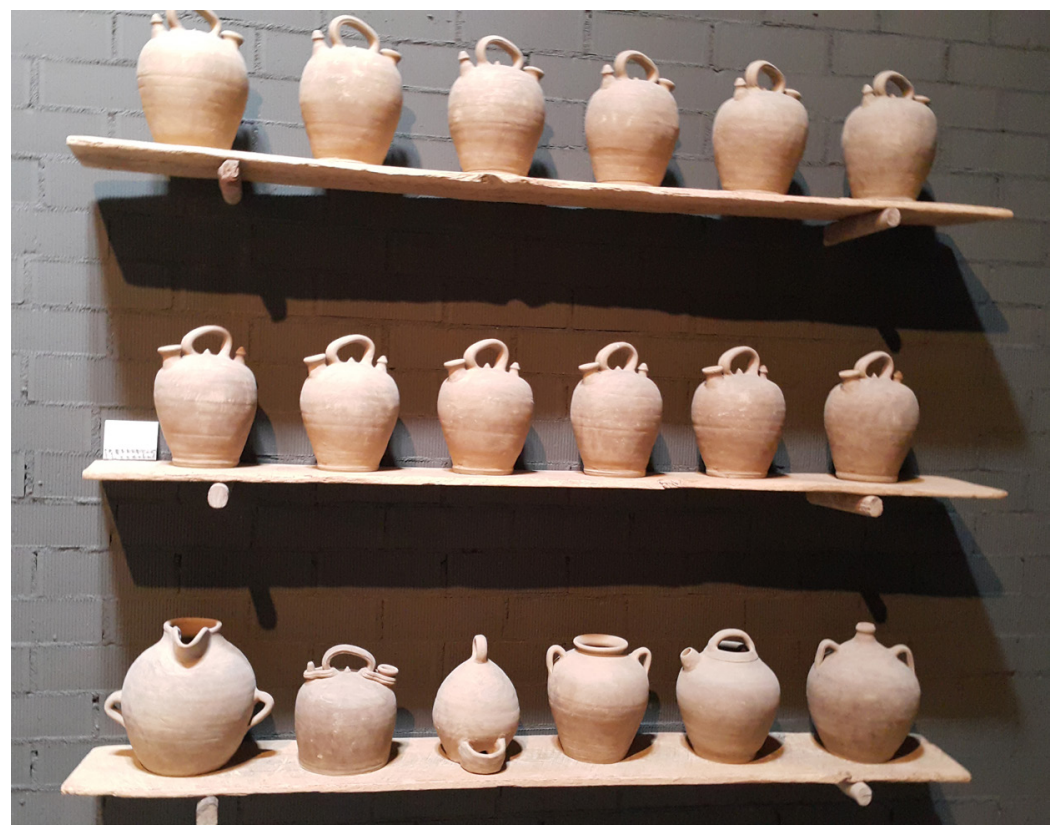

Görsel 3. Katalonya'ya ait geleneksel formlar, cantir testiler, üst 2 sıra, kuşlara su vermek için kullanılan form (alt sırada üçüncü form), denizcilerin kullandığı geniş tabanlı su testileri (alt sırada ikinci form) 


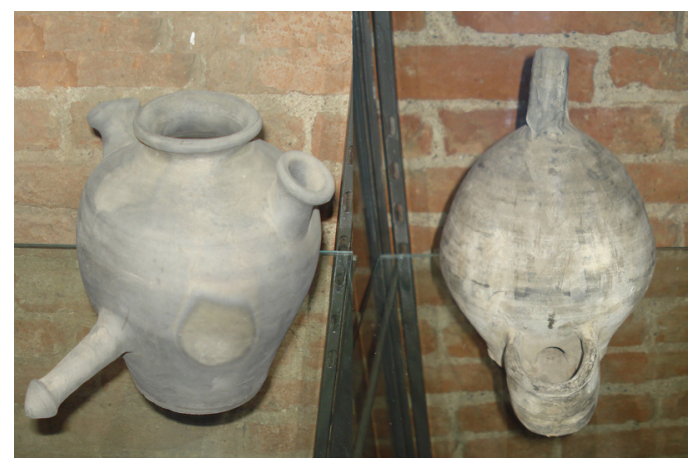

Görsel 4. Arı kovmak için tütsülük, Kuşlara su vermek için kullanılan form

Katalan toplumunun yanı sıra İspanya'ya mal olmuş tüm bu formlar, kültür ve gelenekler açısından önemli değerlerdir. Ancak günümüz dünyasının değişimi oldukça hızıdır. Bu bakımdan geleneklerin değişimin hızına ayak uyduramadığı iddia edilebilir. Fakat bu iddiaya da temkinli yaklaşmak gerekir. Çünkü gelenek demek, sadece somut davranışlar ya da tarzlar demek değildir. Gelenek, aynı zamanda geleceğin inşası için elzem olan "ruh"tur. (Tatar, 2000, 201). Illerleyen zaman sürecinde çömlekçilik sanatındaki durağanlığın yanında endüstriyel üretimlerdeki hızlı gelişmeler, tüm geleneksel kapların yerini plastik, döküm metal gibi malzemelerin almaya başlamasına sebep olmuştur. 100 yıl öncesi gelenekleri günümüzde önemini yitirmiştir. Örneğin su soğutmak için testi Anadolu kültüründe de olduğu gibi İspanya'da da eski önemini ve yaygınlığını yitirmiş, bunların yerini termoslar almıştır. Bu gelişmelerle üretimlerinde yenilik arayışına giren atölyeler, çağdaş seramiklerin üretilmesine olanak sağlamıştır. Çömlekçilik sanatına ve ürünlerine zamanla ilgi azalırken, yeni tasarımlar ve teknik üstünlüğü olan modern seramik ürünler üretilmeye başlamıştır. Bu nedenle günümüzde azalan üretim içinde Quart'ta çömlekçilik sanatı genellikle yemek kapları, küp ve bahçe seramikleri üretimi biçiminde sürdürülmektedir. Her çömlekçi yöresinde olduğu gibi Quart'tada bölgeye ve kültüre dayalı özgün ürünler sınırlı olup satış oranları oldukça düşüktür 100 yıl önce çok yaygın olarak kullanılan ve yukarıda bahsedilen çeşitli formlar, günümüzde tercih edilmemekte, kullanımdan ziyade koleksiyonerler için, hatıra ve dekoratif amaçlı üretilmektedir.

Quart'ta çömlekçilik dört beş kişilik aile işletmeleri olarak beş kuşaktan beri süregelen yukarıda da bahsedildiği gibi Quintana, Prats, Marco, Bonadona ve Mestres atölyelerinde yapılmaktadır. Günümüzde üretilen ürünler kullanım amacına göre boyutlandırılmıştır. Bu ürünlerin başında mutfak kapları, testiler ve küpler gelmektedir. Atölye sahipleri ürünleri daha çok resto- 
ranlara, şarap fabrikalarına ve bahçe dekorasyoncularına satmaktadırlar. Amerika Fransa ve hatta Türkiye'ye satılan büyük şarap küpleri şarabın kalitesini arttırdığından tercih edilse de talep beklenen düzeyde değildir. Quart, pişirim rengi siyah olan karakteristik ürünler ile tanınan bir seramik merkezi olmasının yanında 19.yy'ın başından itibaren kırmızı çamurun orijinal rengiyle de üretimlerin yapıldığı bilinmektedir. Marco ve Bonadona atölyeleri zor şartlar altında geleneksel üretim yapısına, özellikle de siyah pişirim tekniğine sahip çıkmaya çalışırken, Mestres çömlekçilikte gelenekselden çok, çağdaş üretime yönelmeler görülmekte olup, atölyede sadece sofra ve mutfak kapları üretilmektedir. Ticari amaçlı üretilen bu ürünler çok renkli ve klasik üretimden farklıdır. Bunun nedeni günümüz kullanıı kitlelerinin mutfaklarında çok renkli kaplar tercih etmeleri ve artık geleneksel kaplara ilgi göstermemelerinden kaynaklanmaktadır. Bu atölyede sınırlı sayıda yapılan özel üretimler çömlekçi tornasında yapılırken, seri üretimler ise yaş pres yöntemi ile (güveç, çanak, saksı, tabak ve küçük çerez kapları...) üretilmektedir. Geleneksel üretim yöntemlerinin etkisini yitirdiği görülen atölyede geleneksel ürünler gazlı fırınlarda 980-1000 ${ }^{\circ} \mathrm{C}^{\prime}$ de pişirilmekte olup üretim, aynı aileden üç kişi tarafından yapılmaktadır. Atölyede farklı ülkelerden gelen siparişler üzerine yapılan butik üretimlerde ülkelere göre renkler seçilmektedir. Sırlama konusunda Yeni Zelanda için 12 farklı renkten oluşan geniş bir renk yelpazesi kullanılırken, Fransa için sarı yeşil mavi renkler tercih edilmektedir. Seri üretim süreçlerinde astar ve sır kullanarak değişik etkiler elde edilmesi amaçlanmaktadır. Kullanım amaçlı üretilen bu yeni tarz ürünlerin yanı sıra Mestres geleneksel ürünlerin replikalarını da yaparak geleneğin işlev dışında sürmesini sağlamaktadır. Eskiden sadece kırmızı çamurun rengiyle üretilen bazı fonksiyonel kaplar, günümüzde astarlarla renklendirilerek sipariş üzerine üretildiği görülmektedir.
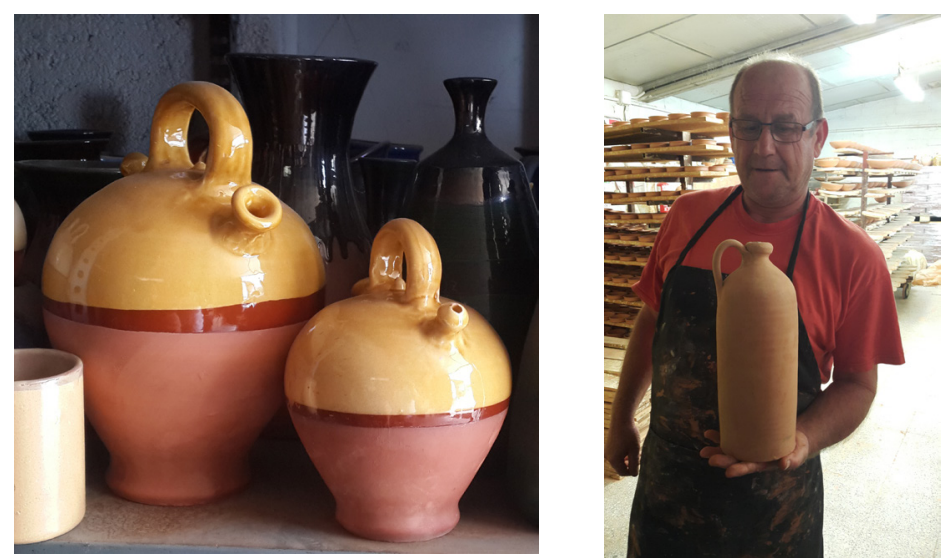

Görsel 5.Atölye Mestres'te renkli cantirler, su testisi (Solda)

Görsel 6. Atölyesinde Josep Mestres ve elinde termofor görevi gören geleneksel testi formu (Sağda) 
Önceden kendi lokal killerini kullanan atölye, rezervler tükendiği için artık şamotlu ve kırmızı çamur olmak üzere çamurlarını satın alarak üzerine dekor yapılabilecek iki farklı çamur türünü tercih etmektedir. Ürünün durumuna göre tek ya da iki pişirim yapılmaktadır. Renkleri, kurşunsuz şeffaf sır altında astar kullanarak elde ettiklerini belirten Josep Mestres, ayrıca sanatçıların üzerine resim yapmak üzere sipariş verdikleri formları da ürettiklerini belirtmektedir. 1740'ta ilk defa üretim yapmaya başlayan bu aile işletmesi, günümüzde beşinci kuşak tarafından sürdürülmektedir. Ailede çömlekçiliği sürdürecek yeni bir nesil yetişmediği için atölye, günümüzde kapanma riski ile yüz yüze gelmiştir.

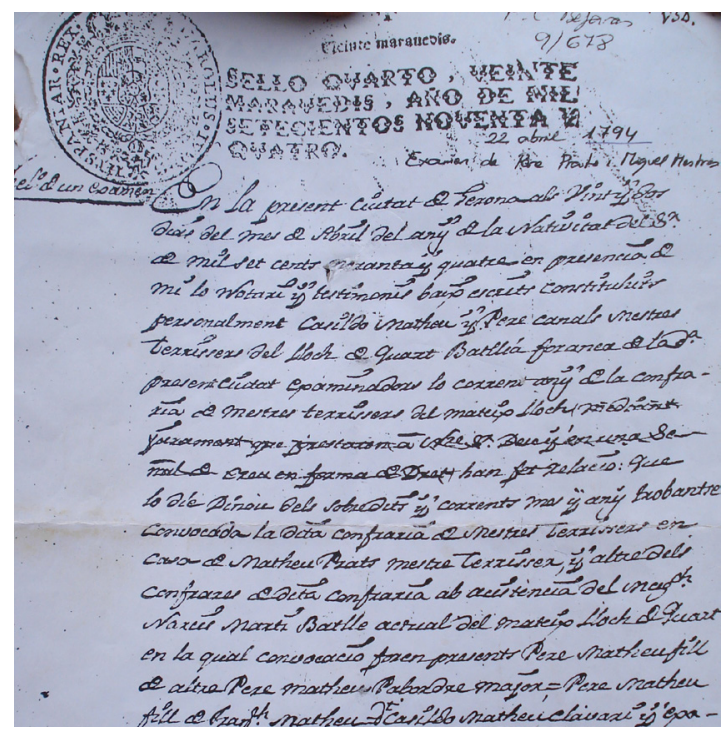

Görsel 7.l 794 yılına ait Atölye Mestres'e ait üretim belgeleri

Ceramiques Marco Quart'ta, Katalonya'da yer alan bir diğer atölyedir. 1473 'te kurulan ilk atölyenin üretimi aynı yerde devam ederek 15. yüzyıldan günümüze ulaşmıştır. Marco ailesi, 19. yüzyıldan itibaren muhtemelen bölgenin en eski atölyesi olarak burada çalışmaya başlamış, günümüzde ise son kuşak olan JaumeMarco Cambo Pilar Alsina Marques tarafından üretim sürdürülmektedir. Jaume Marco ve babası sanatçılarla yaptığı işbirlikleriyle tanınmaktadır. Ünlü Katalan mimar Rafael Maso, 19. yüzyılda Noucentisme sanat akımıyla Girona ve çevresinde yaptığı mimari uygulamalarda bu atölyeyle işbirliği yaparak, her tasarladığı yapıya özgü mimari seramikler sipariş vermiştir. Bunun dışında İspanya'da ve Fransa'da çeşitli heykeltıraşlarla da çalışan Marco, geleneksel çanak çömlek üretiminin yanı sıra sanat seramikleri de üreterek atölyesinin çömlekçilik tarihini değiştirmiş 
ve atölyeyi diğerlerinden ayrıcalıklı bir konuma getirmiştir. Atölyenin günümüz üretimleri daha çok müzelerdeki heykellerin replikaları biçiminde olup üretimlerinde kalıp yöntemi ve bölgeyle özdeşleşen siyah pişirim tekniği kullanılmıştır. Marco atölyesinde, çeşitli sanatçı ve heykeltıraşlarla işbirliği yapılarak Quart geleneğine çağdaş bir yaklaşım getirilmiştir.

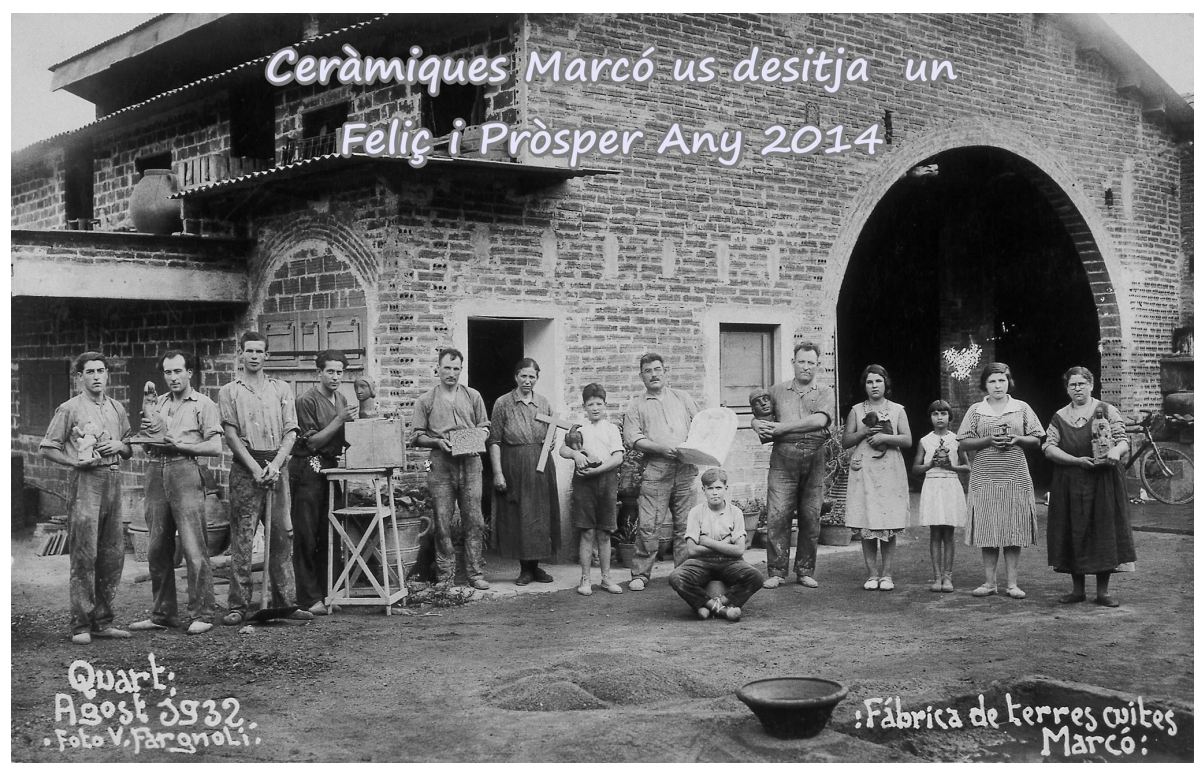

Görsel 8. Atölye Marco, 1932, 3 kuşak bir arada aile fotoğrafı

Marco ve Bonadona çömlekçi atölyelerinde de Mestres'te olduğu gibi şablon torna ve pres yöntemi ile daha büyük boyutlu üretimler dikkat çekmektedir. Geleneksel form üretimlerinin devam ettiği bu atölyelerde boyları 1,5 metreyi aşan küpler, saksılar ve su kapları üretilerek geleneksel siyah pişirim uygulanmaktadır. 

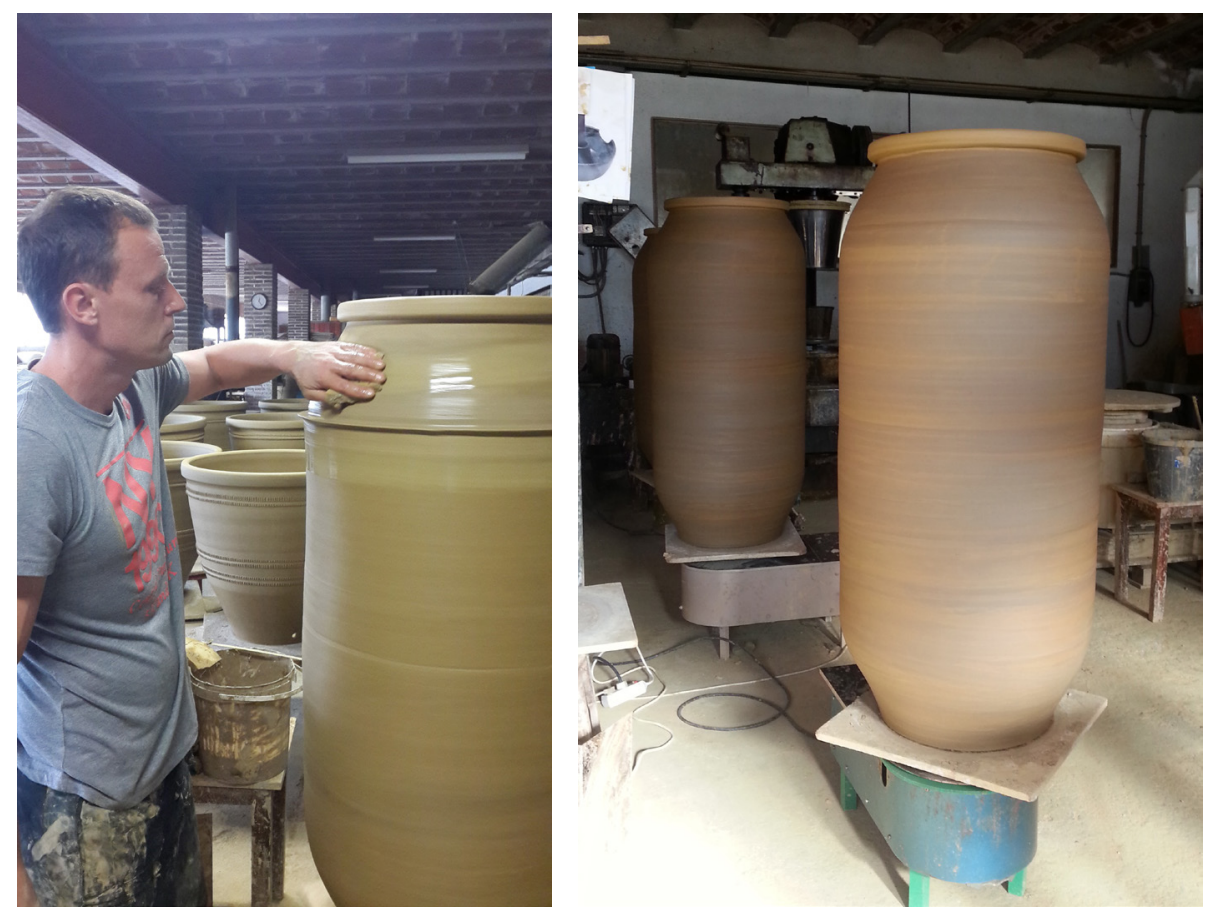

Görsel 9-I0.Atölye Bonadona'da üretim, Quart

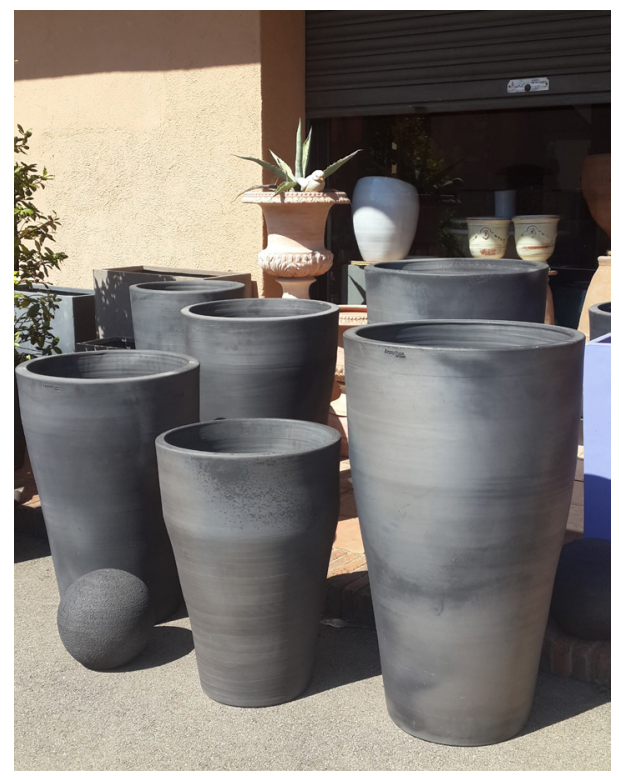

Görsel I I.Atölye Bonadona siyah ürünleri 


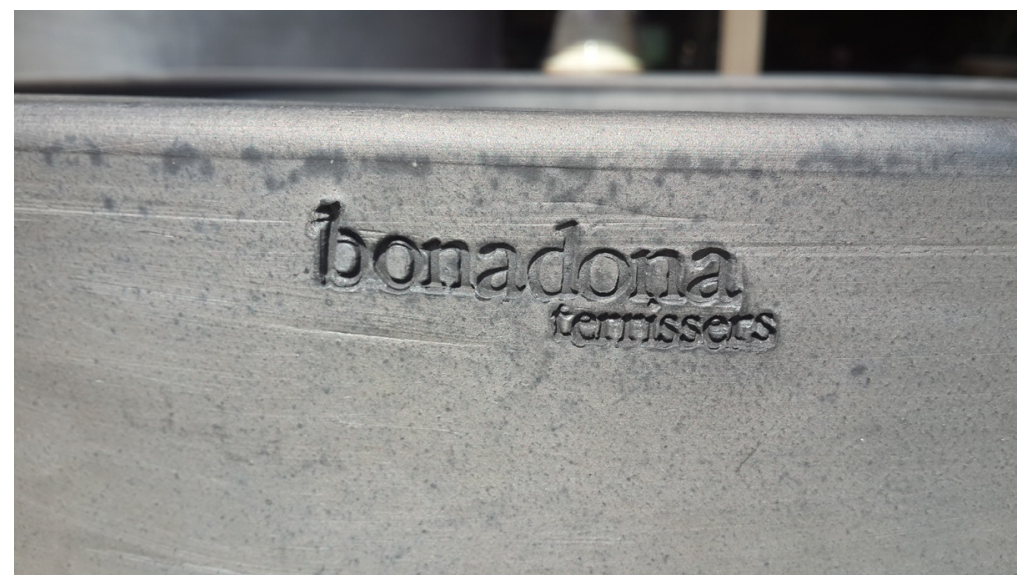

Görsel I2.Atölye Bonadona ürünlerinde kullanılan marka mührü

Quart'ta üretilen ürünlerin şekillendirilmesinde genellikle seramik tornası, pres veya şablon yöntemi kullanılmaktadır. Bu ürünlerin üretim yöntemleri ve geleneksel yapılarının yanında bir diğer önemli özelliği ise siyah pişirim tekniğidir. Geleneksel bir üretim yöntemi olarak bilinen siyah pişirimde yaygın olarak odun kullanılmaktadır. Ürünlerin fırına yüklenmesinde ise; sırsız pişirilen ürünler yığma yöntemiyle, sırlı pişirilen ürünler ise raflarda veya özel pişirim kaplarının içerisinde fırına yüklenerek pişirim gerçekleştirilmektedir.

Çömlekçi fırınları genellikle birbirine benzer özellikler taşıyan çeşitli derecelerde pişirim yapan fırınlardır. Genel olarak geleneksel fırınlarda ülkelere ve bölgelere göre biçimsel, hacimsel ve kullanılan yakıta göre bazı değişiklikler olsa da, amaç aynıdır. Geleneksel fırınların teknik özellikleri üretilecek ürünlerin özelliklerine göre tasarlanmıştır. Çömlekçi ürünleri genellikle $1000{ }^{\circ} \mathrm{C}$ civarında pişirilirken, yüksek ISı gerektiren bünyeler yüksek sıcaklıkta pişirim yapan fırınlarda pişirilirler. Burada önemli olan fırının yapımında yüksek ısıya dayanıklı malzemelerin kullanılmasıdır. Aksi halde fırında büyük deformasyonlar meydana gelebileceği gibi fırının ömrü çok kısalır. Geleneksel üretimde pişirim yapan fırınların teknik ve yapısal özelliklerinin yanında uygulanan pişirim teknikleri de çok önemlidir. Bu durum gelenekseli özgün kılan özelliklerden biridir. Örneğin Türkiye'de güveç kültürü çok yaygındır ve açık dumanlı pişirim tekniğiyle üretilmiş geleneksel güveçler hala tercih edilmektedir.

\section{Quart'ta Siyah Pişirim}

Yaklaşık 300 yıllık çömlekçilik geçmişi olan Quart'ta da Türkiye'de olduğu 
gibi buraya özgü pişirim tekniği olan siyah pişirimler sürdürülmektedir. Siyah pişirim uygulaması burası ile özdeşleşmiş olup yöreye ait bir kimlik oluşturmuştur. Günümüzde siyah pişirim Quart'ta iki atölyede Marco, Bonadona vebunun dışında Verdu (Lleida)'da bir atölyede uygulanmaktadır. Siyah pişirim tekniği ile dumanlı pişirimi karıştırmamak gerekir. Dumanlı pişirim denetimsiz fırın ortamında, açık ortamlarda çukurlarda varil içerisinde yapılan rastlantısal pişirim işlemidir. Yanmanın iyi olduğu kısımlarda ürün, bünyenin hâkim olduğu oksitlerin rengini alırken, yanmanın tam olmadığı, bazı kapalı bölgelerde redüksiyondan ve dumandan dolayı faklı renk geçişleri oluşmaktadır.

Barcelona yakınındaki Verdu Katalan çömlek köyünde Quart'takine benzer siyah pişirim yapılmaktadır. Burada sırsız kapların siyah dumanlı pişirime tabi tutulduğu fırınlara Fas tipi fırın adı verilmektedir. Örneğin Roca Caus firması 1700 yılından bu yana aile geleneği olarak çömlekçiliği sürdürürken, eski bir Arap fırınını da korumuştur. Ürünlerin fırına dizilim aşamasında birbirine temas etmesiyle, açık gri renk efektleri oluşmaktadır.
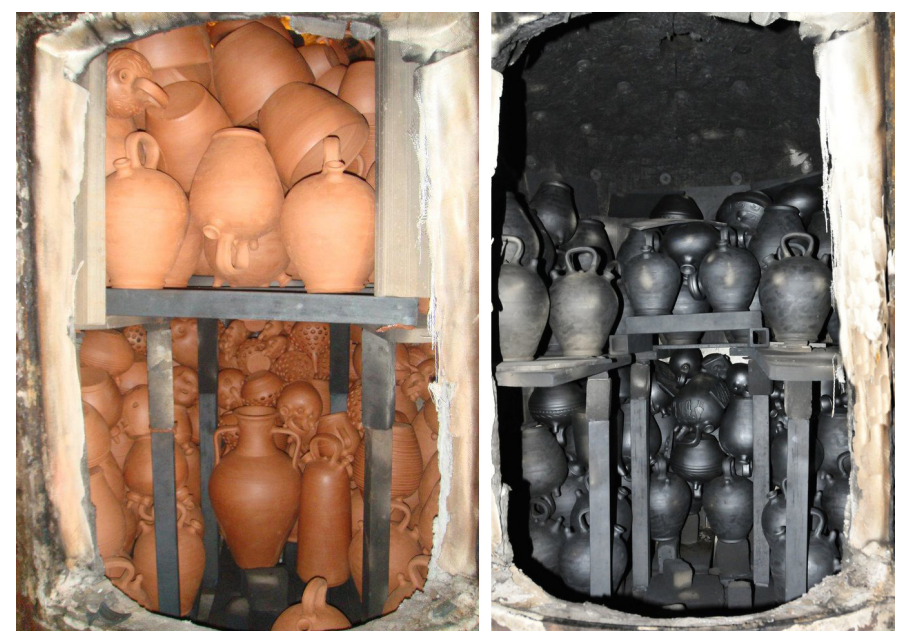

Görsel I3.Atölye Roca Caus, siyah pişirim öncesi ve sonrası firın, Verdu

Quart'ta ise genellikle homojen siyah renk istendiğinden, pişirim için ürünler üst üste dizilirken birbirine değmemesine özen gösterilmektedir. 


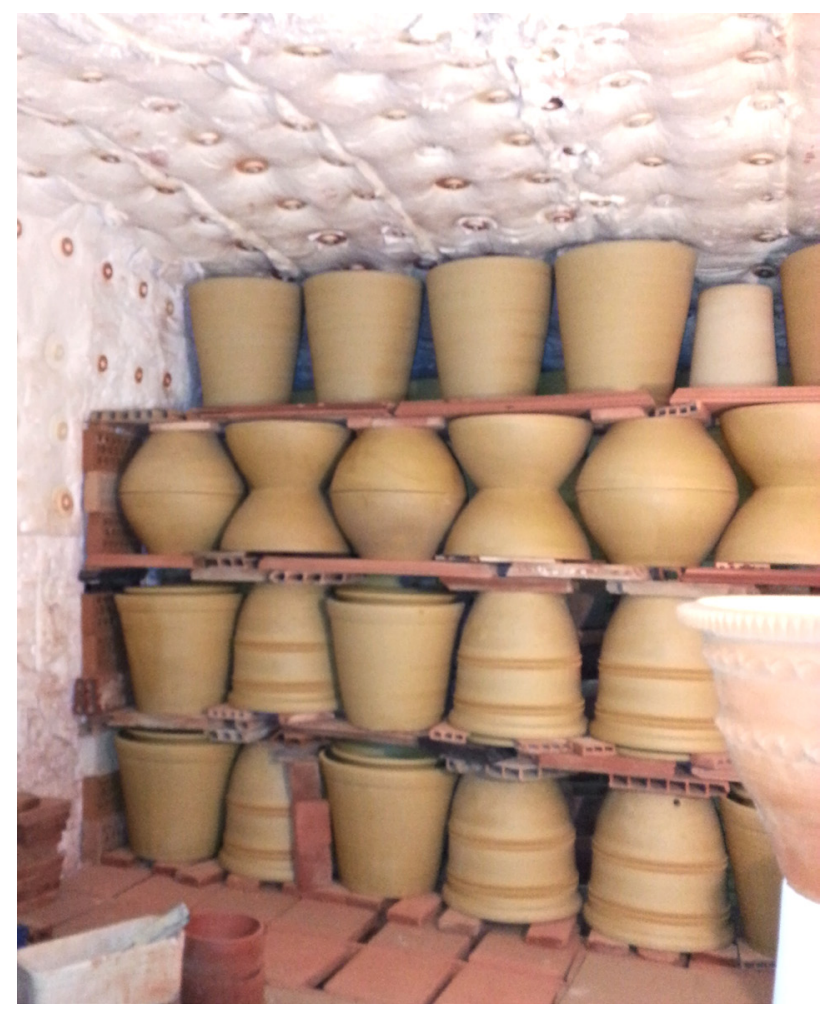

Görsel I4. Atölye Bonadona'da firında dizilmiş ürünler

Siyah pişirilen ürünlerin daha hijyenik olduğuna inanıldığı için özellikle yaz aylarında suyu soğuk tutan botigo kantir testileri kullanılmaktadır. Redüksiyonlu pişirim sırasında kilin içinde bulunan karbon ve oluşan kimyasal yapının bakterileri yok ederek gövdedeki gözenekleri temiz tuttuğuna inanılmaktadır (Hessenberg, 1994: 83).

Quart'tasiyah pişirimin gerçekleştirildiğifırınlarteknikolarakincelendiğinde; bu fırınlarda yer seviyesinin altında ateş bölgesi ile pişirim bölgesi arasında birçok delik ve fırın büyüklüğüne göre bir yükleme kapısı bulunmaktadır. Genellikle iki katlı olan fırınların üzerinde ayrıca fırının büyüklüğüne göre birden fazla delik yer alır. Merdivenle ulaşılan bu delikler, fırının ISı ve atmosferinin gözlemlenmesinde kullanıldığı gibibaca görevide görmektedir. Siyah pişirimin en önemli özelliği fırın içinde ısı $1000{ }^{\circ} C^{\prime}$ ye ulaşıldıktan sonra, çok iyi bir şekilde önce ateşleme ağzının ve sonra bacanın dış hava ile temasının kesiliyor olmasıdır. 


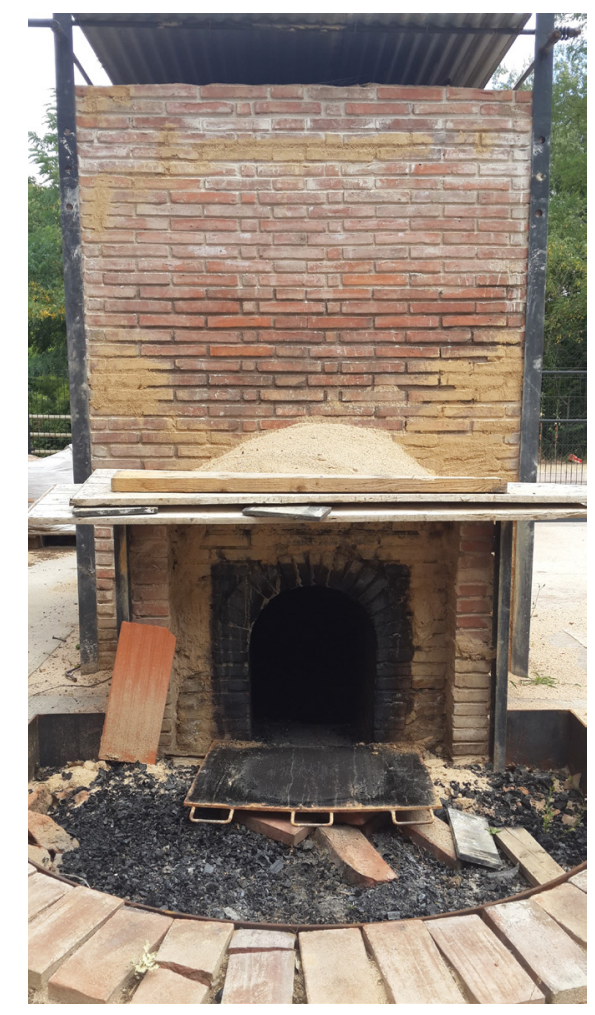

Görsel I5.Quart Müzesi, geleneksel firın dış görünüm

Quart'ta siyah pişirim yapılacak olan ürünler özellikle kırmızı çamurdan biçimlendirilerek, kuruma esnasında bir bezle silinerek parlatıır. Bu işlem ürünlerde siyah parlak bir etki verilmesini sağlar. Fırının yüklenmesi esnasında ürünler, birbirini örtmeyecek veya fazlaca birbirine değmeyecek şekilde dizilerek yükleme işlemi yapılır. Frının iç ve dış kısmında tuğlaların arası yaş çamurla sıvanarak izolasyon sağlanır. Yüklemesi tamamlanan fırın yakılmadan önce ağzı tuğla ile örülerek ıslak toprak, kum ve kalaslarla sıkıca hava almayacak şekilde kapatılır.

Ateşleme ve pişirim bölgesinden oluşan ỉki katı ı fırın, yer seviyesinin altında kalan ateşleme bölgesinden odunla beslenerek, ateşlenir. Fırındaki ürünlerin arasında ilerleyen alevler ürünlerin arasından dolaşarak üstteki gözetleme görevi gören deliklerden çıkar. Tuğla parçası yardımı ile istenildiği kadar açılıp kapatılan bu delikler; aynı zamanda, alevlerin fırında homojen dolaşması, daha çok kalabilmesi, ısının fırın içindeki dağılımını kontrol edilmesi ve fııın içindeki hava akımının ayarlanmasına yardımcı olması için de kullanılır. 


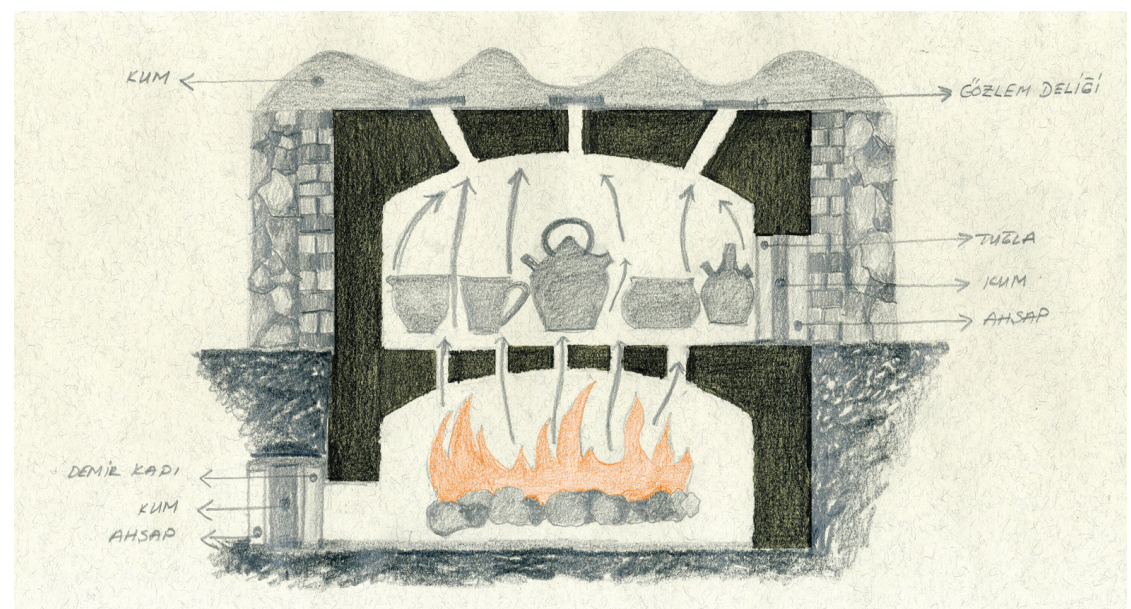

Görsel 16. Iki katlı siyah pişirim fırın kesiti, Altta ateşleme bölümü, üstte ürün yükleme bölümü
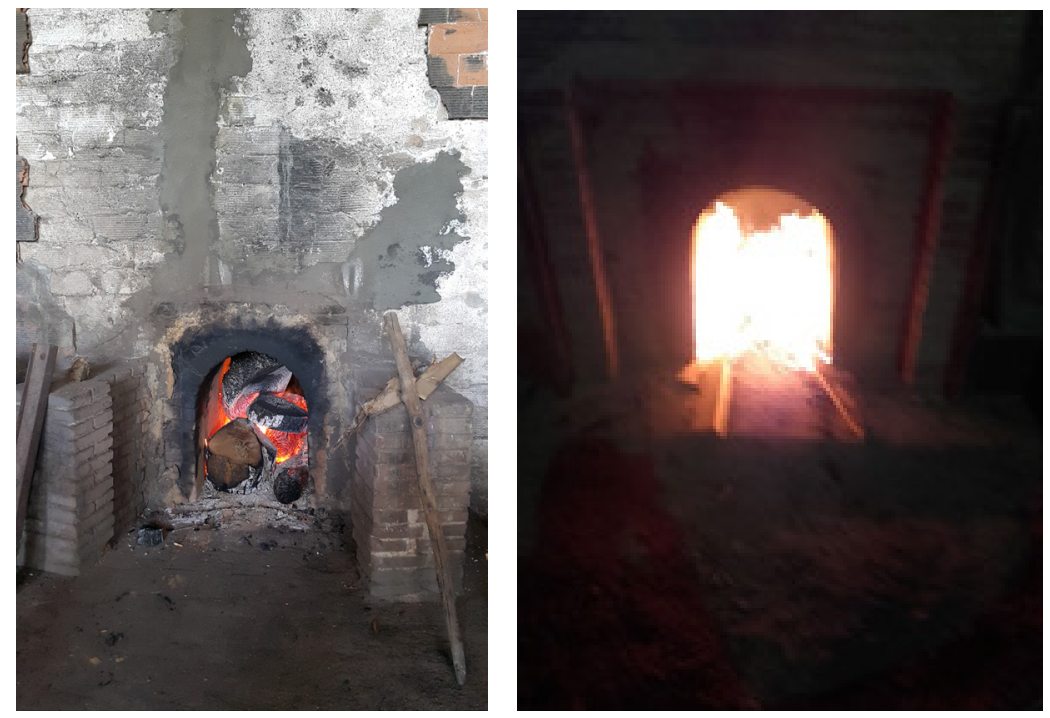

Görsel 17. Fırının odunla alt bölgeden ateşlenmesi

Ustalar bu deliklerden bakarak yeterince odun yakılıp yakılmadığına da karar verirler. Fırın $1000{ }^{\circ} C^{\prime}$ ye geldiğinde geleneksel siyah rengin gerektirdiği atmosferi redüksiyon ile sağlamak için, oksijenin kesilmesi gerekmektedir. Bu aşamada kor halindeki közler ateşleme bölgesinden alınarak, uzaklaştırıır. Daha sonra fırına yaş odun yükleyerek önce fırının ateşleme ağzı, toprak ve kalaslarla hiç hava almayacak şekilde kapatılarak 
ıslatılır. İkinci aşama olarak delikler seramik kırıkları, kum ile tamamen hava almayacak şekilde kapatılarak oksijensiz karbonlu indirgen ortam oluşturulur.

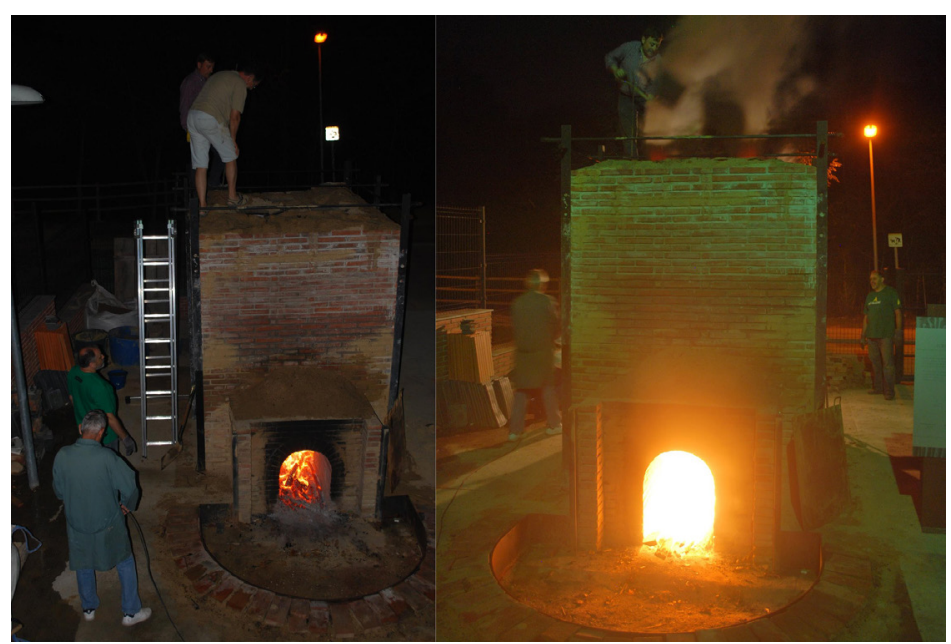

Görsel 18. Fırının üst deliklerin gözlem sonrasında aşamalar halinde kapaklarla ve kumla kapatılması

On beş gün süresince fırın kapalı tutularak karbonun ürünlerin içerisine kadar işlemesi sağlanır. Böylece ürünler karakteristik siyah rengini almaya başlar. Fırının soğutulmasıyla birlikte boşaltılması da oldukça zahmetlidir. Bu durum fırının büyüklüğüyle de ilgilidir. Pişirimle birlikte 15 gün geçtikten sonra, doldurma kapısından küçük bir delik açılarak, soğumanın hızlanması sağlanmaktadır. Bu arada yakma ağzındaki toprak ve kalaslar sökülerek yakma haznesinde kalan tam yanmamış odun kömürleri alınarak fırının tam olarak boşaltılacak sıcaklığa düşürülmesi sağlanır. Daha sonra fııın kapısındaki kalaslar ve izolasyon toprağı alındıktan sonra doldurma ağzı iyice açılarak fırından ürünlerin boşaltma işlemi yapılır.

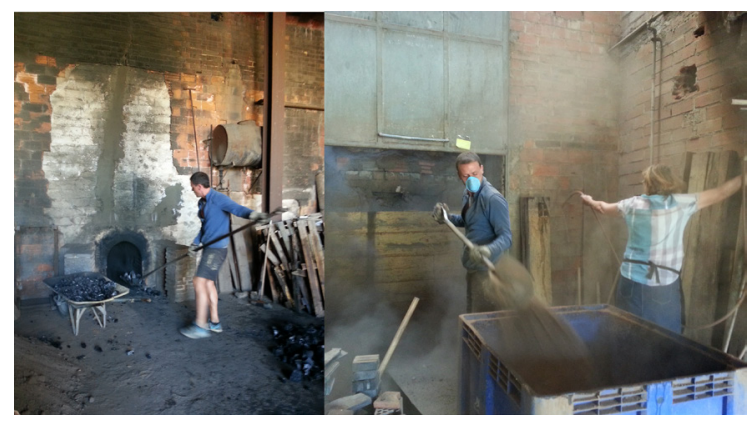

Görsel 19. Fırından kömürlerin alınıp soğutulması

Kapağın açılması için kalasların ve toprağın alınması 
Quart çömlekçi köyünde siyah pişirim sürecinin her aşaması incelendiğinde, bu teknikle pişirilen ve kültürün özelliklerini yansıtan ürünlerin, çok zorlu bir süreçle elde edildiği görülür. Bu zahmetli üretim süreciyle ortaya çıkan yöreye özgü siyah ürünler, kendine has metalik görünümün etkisiyle dikkat çekerken, diğer yöredeki ürünlerden ayrılmaktadır. Bu kadar zorlu süreç sonunda elde edilen ürünlerin kimliğinin kaybolmaması ve tekniğin sürmesi için gerekli tanıtımın yapılarak bu işlemin dünya kültür mirası olarak tanıtılması ve aktarılması gerekliliği ortaya çıkmaktadır.

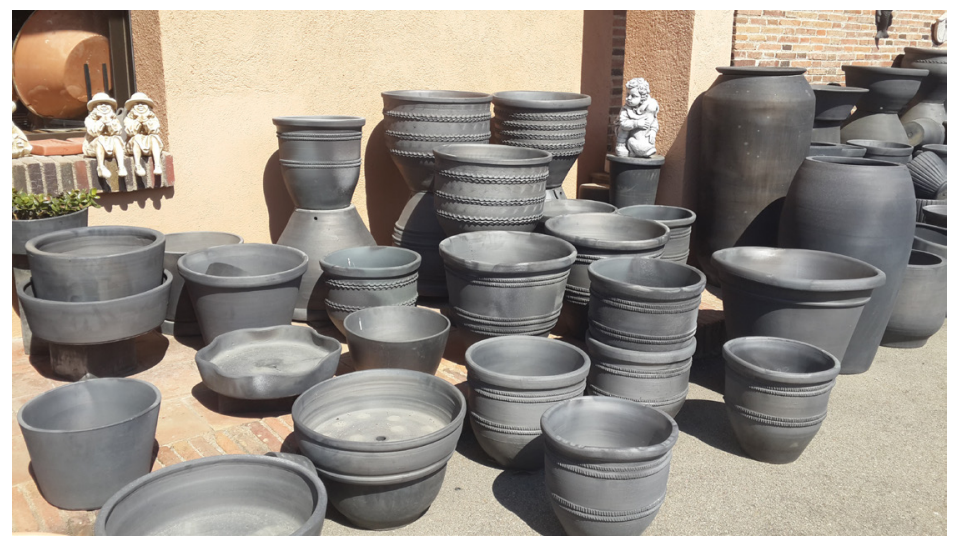

Görsel 20.Atölye Bonadona, siyah pişirim sonrası fırından çıkan ürünler

\section{Sonuç}

Toplumların kültür ve gelenekleri yaşadığı, sürdürüldüğü ve kullanıldığı müddetçe varlı̆̆ını sürdürmeye devam eder. Quart'ta uzun yıllar kullanılan ve gelenekselleşen siyah pişirim tekniği artık çömlekçilik sanatının güncelliğini yitirmesi ile yok olma aşamasına gelmiştir. Tekniğin tanıtılması ve geleneğin yaşatılması adına Quart'ta eski bir fabrika restore edilerek müze haline getirilmiştir. La Terissa de Quart müzesi 1926 yılında kurulan Can Ginesta tuğla fabrikasının üretim hattının orijinal haliyle korunmasıyla 2010 yılında açılmıştır. Açıldığı günden bu yana çeşitli seramik etkinliklerine ev sahipliği yapmaktadır.

Bu kapsamda seramikle ilgili çalışmalar bununla kalmayıp, 2016 Temmuz ayında da seramik sanatçılarının davet edildiği 1. Uluslararası Negra Seramik Sempozyumu, siyah pişirim tekniğinin seramik sanatçılarına tanıtılmasına ve uygulanmasına olanak sağlanmışır. Uluslararası platformda organize edilen bu sempozyum, Quart Belediyesi ve akademisyenlerin işbirliği ile gerçekleştirilmiştir. Geleneğin, kültür ve tekniklerin kaybolmaması adına 
gerçekleştirilen bu organizasyon, çömlekçilik sanatının ve kültürünün geleceğe aktarılması adına olumlu, önemli bir gelişmedir.

$\mathrm{Bu}$ anlamda etkinlikleri kendi atölyesinde organize eden Jaume Marco Cambo Pilar Alsina Marques, yeni jenerasyonun aile üretimine katkı sağlamadığı ve bu geleneği sürdürmediğini belirtirken, kendisini ve eşinin seramik ile ilgili çeşitli projelere devam etmekte olduğunu açılamıştır. Seramik Okulu La Bisbal ve El Sanatları Merkeziyle ortaklaşa sınır ötesi bir projesi hazırlamaktadır. Marco'nun Katalonya Sanat Derneği aracılığıyla, Escola Massana ile Siyah Seramik seminerleri düzenlemesi geleneksel Quart siyah çömleklerinin gelecekte sona ermemesi için gösterilen önemli bir çabadır. Gelenekler, kültürel, toplumsal değerler bu şekilde paylaşıldığı müddetçe yaşarlar gelişirler. Quart geleneği olan siyah pişirme yöntemi de kuşaktan kuşağa günümüze ulaştığı gibi, gelecek kuşaklara da aktarılarak, geliştirilmesi, seramik sanatına ışı tutmaya devam etmesi gereken bir değerdir. 


\section{Kaynakça}

Celio, S. (20/4). La Alfarereia Relacionado con Los Animales. Barcelona: Burgos Seramik Müzesi Yayınları.

Hessenberg, K.(1994). The Saw dust firing. Philedelphia: Editor Emmanuel Cooper, Press Pennysylvania,

Tatar, T. (2000). Gelenek ve Gelecek. Sosyoloji konferansları Dergisi, İstanbul Üniversitesi, sayı 26., s. 199-215

Terrissa de Quart Seramik Müzesi Kataloğu, İspanya

Josep Mestres, Bonadona Seramik Atölyelerinde ve Quart seramik müzesinde yetkililerle yapılan röportajlar, Quart, İspanya

\section{İnternet Kaynakları}

www.museuterrissa.cat

https://sortidesambgracia.com/2015/07/I I/el-museu-de-la-terrissa-de-quart/

www.museucantir.com

www.bonadona.cat

http://ceramicarocacaus.com/

Quart seramikçiler derneği web sitesi

https://www.facebook.com/terrissersdequart/

\section{Görsel Kaynaklar}

Görsel I ve 2. La Bisbal Seramik Müzesi, İspanya Fotoğraf, yazar arşivi

Görsel 3. La Bisbal Seramik Müzesi, İspanya Fotoğraf, yazar arşivi

Görsel 4. La Bisbal Seramik Müzesi, İspanya Fotoğraf, yazar arşivi

Görsel 5. Atölye Mestres Quart Fotoğraf, yazar arşivi 
Görsel 6. Atölyesinde Josep Mestres, Quart Fotoğraf, yazar arşivi

Görsel 7. Atölye Mestres, Quart Fotoğraf, yazar arşivi

Görsel 8. Erişim Tarihi, 02. 08.2016 https://www.facebook.com/ceramiquesmarco/ photos/a.247282 I92 I03766.107374 I829. I 78902072275 I / 2/255549/37943738/?ty pe $=3 \&$ theater

Görsel 9. Atölye Bonadona, Quart Fotoğraf, yazar arşivi

Görsel 10. Atölye Bonadona, Quart Fotoğraf, yazar arşivi

Görsel II. Atölye Bonadona, Quart, Fotoğraf, yazar arşivi

Görsel I2. Atölye Bonadona, Quart, Fotoğraf, yazar arşivi

Görsel 13. Erişim Tarihi, 20. 09.2016 https://www.facebook.com/photo.php?fbid =36428 59762909\&set $=p b .1616801798 .-2207520000.1519646882 . \&$ type $=3 \&$ theater

Görsel 14. Atölye Bonadona, Quart, Fotoğraf, yazar arşivi

Görsel 15. Fotoğraf, yazar arşivi

Görsel I6. Çizim: Saime Dönmezer

Görsel 17. Erişim Tarihi, 10.08.2016 www.bonadona.cat

Görsel I8. Erişim Tarihi, 28.09.2016

https://www.facebook.com/terrissersdequart/photos/

pcb. I 746435255629603// 746434/95629709/?type =3\&theater

Görsel 19. Atölye Bonadona, Quart, Fotoğraf, yazar arşivi

Görsel 20. Atölye Bonadona Quart, Fotoğraf, yazar arşivi 